Bulgarian Academy of Sciences. Space Research and Technology Institute.

Aerospace Research in Bulgaria. 32, 2020, Sofia

DOI: https://doi.org/10.3897/arb.v32.e17

\title{
ZEOLITES APPLICATION IN TERRESTRIAL AND SPACE INDUSTRY - A REVIEW
}

\author{
Adelina Miteva ${ }^{1}$, Valeria Stoyanova ${ }^{2}$

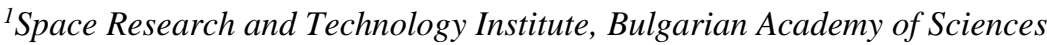 \\ ${ }^{2}$ Institute of Physical Chemistry, Bulgarian Academy of Sciences \\ e-mails:ad.miteva@gmail.com,valeria@ipc.bas.bg
}

Keywords: Zeolite Synthesis; Catalysis, Adsorption and Ion Exchange; Space Applications; Fuel; Water and Gas Purification

\begin{abstract}
This brief overview presents an attempt to systematize some of the available historical and recent data on the impact of zeolite science and engineering on the progress of various areas of Earth and Space development. The basic structural and chemical properties of natural and synthetic zeolites are presented. Valuable applications of the zeolites, such as catalysts, gas adsorbers and ion exchangers are also included. The most commonly used methods for the synthesis of zeolites from different materials are presented, as well as some Bulgarian developments for the reuse of waste materials to zeolites. The important role of zeolites as an indispensable material for improving the quality of soil, fuels, water, air, etc., required for the needs of orbiting space stations and spacecrafts has been confirmed by typical examples.
\end{abstract}

\section{Aim and scope}

The aim of this review is to briefly outline the application of zeolites in the vast field of aerospace engineering and the launch industry. Zeolitic materials are indirectly related to improving the quality of production of satellites, ground equipment, aviation and spacecraft flights, fuels, water and air purification in aircraft, as well as ensuring the safety of passengers and crew. Some of the general structural and chemical concepts are presented here, such as aerospace terms, catalysis, ion exchange and cracking, the main zeolite properties, materials, etc. Mentioned here are also some Bulgarian achievements.

\section{Zeolites and their main properties}

Zeolitites are a large group of crystalline minerals having microporous and regular structure $[1,2]$. This definition usually refers to the natural zeolitic minerals, but it also refers to a synthetic crystalline substance with zeolitic properties, i.e. a material with a crystal structure formed by a three-dimensional 
open framework of tetrahedra with inner channels and cavities providing the material with the capabilities of ion exchange and reversible dehydration. The main differences between natural and synthetic zeolites are the time scale in which they are produced, the amount of material that is produced and the quality of zeolites. The great advantage of natural zeolites is the volume and quantity that they can extract, unlike the relatively low volumes produced in the laboratory, but only the creating of synthetic zeolites can provide materials with certain desired properties tailored to the specific industrial needs. The number of naturally occurring zeolite types is about 40, and the artificially synthesized zeolites are almost 200 unique frameworks [2]. More information about both, natural and synthetic zeolites can be found in the International Zeolite Association (IZA) web pages such as, for instance: http://www.iza-structure.org/databases/.

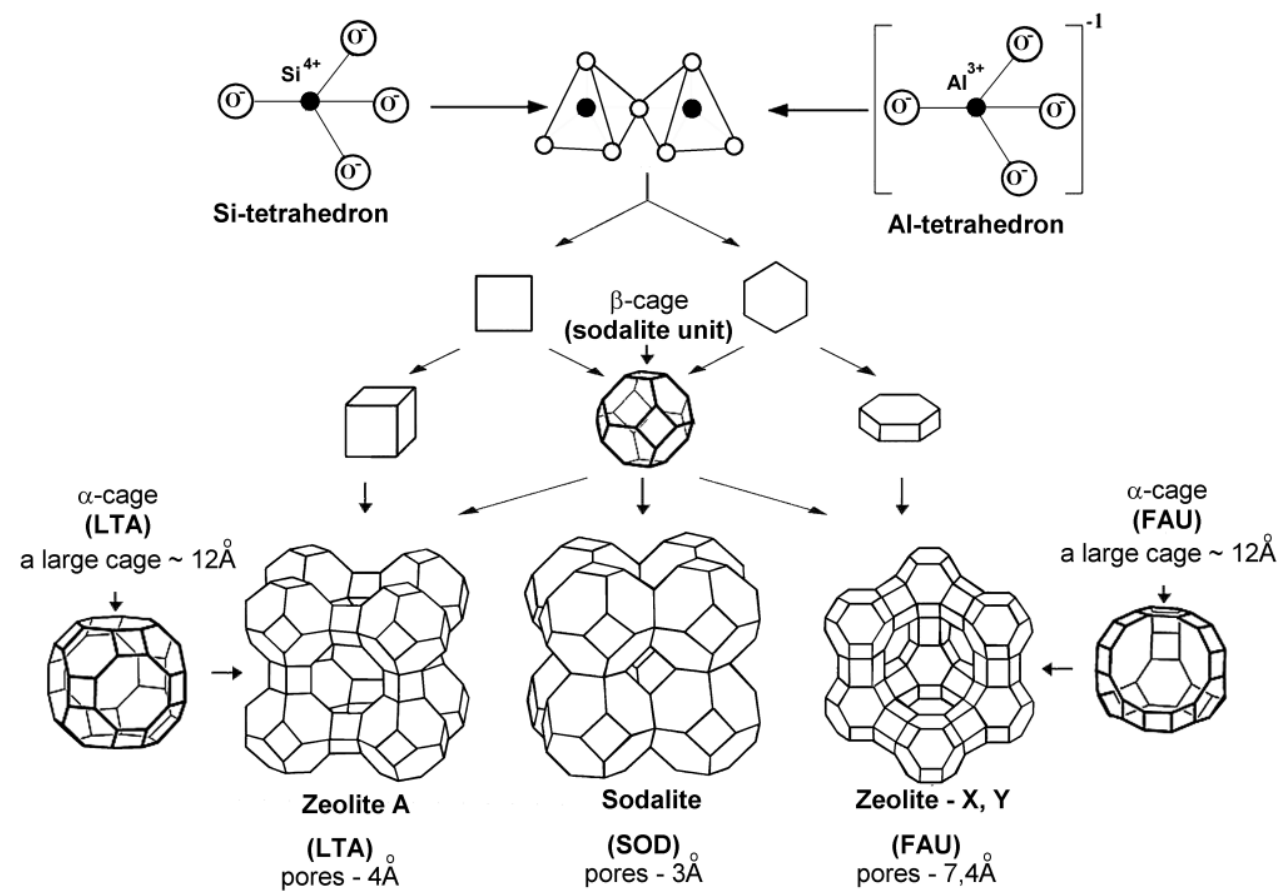

Fig. 1. Examples of building units and pore / cage sizes of three zeolite structures: zeolite A (LTA), sodalite (SOD), and faujazite (FAU) - zeolites X, $Y$

The composition of zeolites can be represented by the general formula $\mathrm{Mx} / \mathrm{n}\left[\left(\mathrm{AlO}_{2}\right) \mathrm{x}\left(\mathrm{SiO}_{2}\right) \mathrm{y}\right] \cdot \mathrm{zH}_{2} \mathrm{O}$, where $\mathrm{n}$ is the charge of the metal cation $\mathrm{M}$, and the values of $\mathrm{x}, \mathrm{y}$ and $\mathrm{z}$ depend on the type of zeolite. For example, the respective formula for zeolite $\mathrm{NaA}$, also known as LTA (Linde Type A), is $\mathrm{Na}_{12}\left[\left(\mathrm{AlO}_{2}\right)_{12}\left(\mathrm{SiO}_{2}\right)_{12}\right] .27 \mathrm{H}_{2} \mathrm{O}$, implying that zeolite LTA has 12 tetrahedra in 
every cell unit, occupied by $12 \mathrm{Na}$ atoms and $27 \mathrm{H}_{2} \mathrm{O}$ molecules. Zeolites $\mathrm{X}$ and $\mathrm{Y}$ belong to the group of faujasite (FAU), faujasite- $\mathrm{Na}$, faujasite-Mg or faujasite-Ca, having the same basic formula: $\left(\mathrm{Na}_{2}, \mathrm{Ca}, \mathrm{Mg}\right)_{3.5}\left[\mathrm{Al}_{7} \mathrm{Si}_{17} \mathrm{O}_{48}\right] \cdot 32\left(\mathrm{H}_{2} \mathrm{O}\right)$. The structures of these three types of zeolites are presented in Fig. 1.

Zeolitic materials are readily dehydrated and rehydrated, and can be used as cation exchangers (removal of metal cations from wastewaters, detergent ingredient), absorbers (for gases and liquids), molecular sieves (membranes, purificators), catalysts (petrochemistry, environmental issues, fine chemicals) etc. Due to these specific structural peculiarities, they are invaluable in chemical industry, and also in development of various traditional and modern fields, like green chemistry, hybrid materials, medicine, animal food, soil improvement, optical and electrical based applications, microsystems and nanotechnology, etc. The morphology and size of zeolite crystals could have also important impact on their applications. Besides, from a practical point of view, zeolites are environmental-friendly in technological processes.

\section{Aerospace sector}

The aerospace industry refers to Class 3530 of the United Nations' International Standard Industrial Classification (ISIC) which covers the manufacture of aircraft and spacecraft. This broad class comprises the manufacturing of both non-space items (passenger and military aeroplanes, helicopters, gliders, balloons, etc.) and space items (including spacecraft, spacecraft launch vehicles, satellites, planetary probes, orbital stations and shuttles). This also includes the manufacturing of their parts and accessories, used in civil or military applications, such as aircraft instrumentation, navigation and control systems, ignition parts and other electrical parts for internal combustion engines, space radio and telemetry systems, etc. [3, 4].

\section{Scientific interest to zeolite growth in space}

An important impetus for writing this review is the longstanding and growing interest in the topic of the zeolites and their current and future use not only on earth but also for the needs of the space industry.

Since the first flight of the Wright brothers in 1903, the humankind has come a long way, and in 2019 we have not only commercial aircraft for more than 850 passengers at once, but also a great variety of business and private aircrafts, such as airplanes, helicopters, drones, etc. Currently, we have more than 4800 satellites in orbit around the earth. In 2018 was tested the newest solar aircraft that stayed in flight for almost a month. One of the greatest achievements in engineering space industry is the International Space Station that is a low orbit space research center. 
NASA's effort to stimulate commercial use of space, it is "to enlarge the technology base on which to build new commercial space industries and to help move emerging technologies from the laboratory to the marketplace with speed and efficiency" [4]. The Battelle center has sponsored experiments on eight Space Shuttle missions since 1990. The huge potential of the zeolites has aroused great interest among space competitors. Two NASA Space Commerce Centers (Battelle Advanced Materials Center, Columbus, Ohio, and Clarkson Center for Commercial Crystal Growth, Potsdam, New York) have merged their endeavours with a number of industrial and academic institutions, sending to fly 38 sample zeolite solutions in 1992 Shuttle mission. Results of that flight were applied to a zeolite growth experiment package flown aboard STS-57 in 1993. The clear conclusion was that zeolite crystals, which have wide and important significant commercial potential, can be grown larger and more efficient with fewer defects in orbit (Fig. 2).
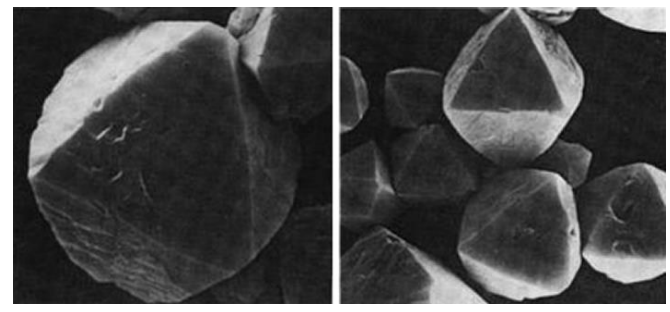

Fig. 2. Zeolite crystals, which have significant commercial potential, can be grown larger and with fewer defects in orbit. This photo compares orbit-grown (left) and Earth-grown zeolite crystals (right) [4].

\section{Main zeolite applications}

The three main applications of zeolites in the fields of catalysis, gas adsorption and ion exchange are schematically presented in Fig. 3 and are briefly described below [2]:

Catalysis: It is the most important application of zeolites in industry and benefits from a zeolite framework with well-defined pores and acidity. The largest application is the Fluid Catalytic Cracking (FCC) process, which is used for production of gasoline from heavy oil through cracking. Zeolite $\mathrm{Y}$ is the key component in the FCC catalysts, due to it pore size, and high activity provided by acid sites when is ion exchanged with rare earth or hydrogen cations. For example, ZSM-5 zeolite is used extensively as catalyst in the petrochemical industry.

Gas Separation: Adsorption is a common phenomenon in which a part of gas or liquid in contact with a solid is retained and concentrated at its surface. Zeolites are widely used in adsorption-related applications. Gas separation through adsorption may be achieved via the strength of adsorption (selective adsorption) or 
rate of adsorption (molecular sieving by size and shape). Acid gases, such as $\mathrm{HCl}$, $\mathrm{SO}_{3}$, and $\mathrm{NO}_{2}$ are strongly adsorbed on molecular sieves because of their polarity but are accompanied by degradation of the molecular sieve crystalline structure. Other gases, such as $\mathrm{CO}_{2}, \mathrm{SO}_{2}$ and $\mathrm{H}_{2} \mathrm{~S}$ are reversibly adsorbed. Examples of gas separation by selective adsorption using zeolites are the selective uptake of $\mathrm{CO}_{2}$ over $\mathrm{N}_{2}$ and separation of $\mathrm{CO}_{2}$ from natural gas or synthesis gas. An example of gas separation by molecular sieving zeolites is the separation of xylene isomers.

Ion exchange: The ions held in channels and cavities of zeolites are exchangeable and zeolites can take up cations from mixtures with other cations. For instance, zeolite A is applied industrially as detergent builder to takes up $\mathrm{Ca}$ ions from water, and exchanges them with $\mathrm{Na}$ ions of the zeolite, which makes the water soft. The success of zeolite A as detergent is due to its high and fast calcium uptake, good dispersibility, low sedimentation tendency, low abrasiveness and high degree of whiteness. Zeolite crystals should have a small particle size (around $4 \mu \mathrm{m}$ ) and narrow particle size distribution.



Gas separation

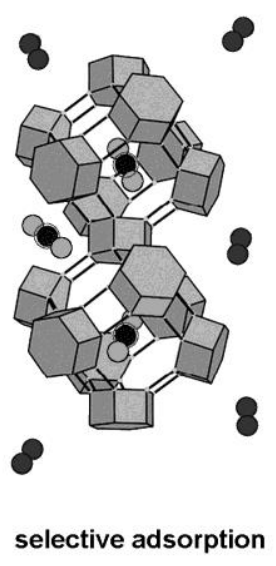

lon exchange



Fig. 3. Schematic illustration of the three main applications of zeolites: catalysis, gas adsorption and ion exchange [5]

\section{Water and wastewater treatment}

The most prominent features of zeolites include the exchange of undesirable cations and the absorption of inorganic and organic molecules of specific dimensions. Their values of high mechanical strength, chemical stability and abrasion make zeolites a special material for softening and purifying drinking and industrial waters, as well as many other applications [6]. The negative charges 
act as a magnet to attract positively charged toxins, heavy metals and some radioactive elements. Due to their large surface area and porosity, zeolites are perfect catchers for bacteria.

As a rule, the greater the $\mathrm{Al}$ content corresponds to the higher cation exchange capacity of the zeolite. The negative charge at $\left[\mathrm{AlO}_{4}\right]^{-}$-tetrahedra is compensated by easy replaceable metal-cations such as $\mathrm{Na}^{+}, \mathrm{K}^{+}, \mathrm{Ca}^{2+}, \mathrm{Mg}^{2+}$, etc., that determine the ion-exchange ability of zeolites for effective removal of pollutants from contaminated waters. The most common cation in synthetic natural and natural zeolite structure is $\mathrm{Na}^{+}$, which can be easily replaced from aqueous solution, e.g. by $\mathrm{Sr}^{2+}$ or $\mathrm{Cs}^{+}$ions.

\section{Softening}

Nowadays, most of the commercial washing powders contain zeolite, instead of harmful phosphates. Zeolites are widely used in industrial water softening systems and in domestic "on the tap" filters, since they could be easily regenerated. Zeolite $\mathrm{NaA}$ is nontoxic to fresh and marine waters, and is the first zeolite introduced as a water softener in laundry detergents in 1978. Similar behaviour has the zeolite NaP. Especially valuable appears to be the zeolite $\mathrm{X}$, that due to its larger pore diameter of $0.74 \mathrm{~nm}$ has higher magnesium binding capacity compared to zeolites A and P [6]. It was successfully introduced into detergents market a dozen years ago. Synthetic zeolite $13 \mathrm{X}$ and the natural clinoptilolite have been also reported for use in detergent formulations. Experiments show that zeolite $\mathrm{A}$ and zeolite $\mathrm{X}$ were more effective in cleaning than clinoptilolite at low temperatures, while all these builders had the same effectiveness at high temperatures. Due to the advantageous builder properties of zeolites combined with their human and environmental safety, they have been included in an extensive range of detergent industry. In Europe, the USA, Japan and several regions of East Asia, zeolites have almost entirely replaced phosphates.

\section{Ammonia removal}

Ammonia in the environment originates from metabolic, agricultural and industrial processes and from water disinfection. Ammonia in water is an indicator of possible bacterial, sewage and animal waste pollution, and may have harmful effect on human and animal health. Natural clinoptilolite has higher selectivity for $\mathrm{NH}^{4+}$ ion than synthetic zeolites. Despite of their lower selectivity to ammonia ion, synthetic zeolites, namely types $\mathrm{A}, \mathrm{X}$ and $\mathrm{Y}$, have much higher ammonia exchange capacity than naturally occurring zeolites [6].

\section{Heavy metals removal}

Heavy metals, like $\mathrm{Cd}, \mathrm{Cr}, \mathrm{Cu}, \mathrm{Ni}, \mathrm{Zn}, \mathrm{Pb}$ and $\mathrm{Hg}$, are well known with their toxicity. Some of them tent to accumulate in living organisms, and may cause serious health effects, including reduced growth and development, cancer, organ damage, nervous system damage, and even death. Many natural and synthetic 
zeolites have been widely explored for heavy metals immobilization form natural or industrial water. The number of the scientific articles devoted on this problem in the past ten years exceeds one hundred. Clinoptilolite, $\mathrm{NaA}, \mathrm{NaP}, \mathrm{NaP} 1, \mathrm{NaX}$ are among the most studied zeolites for adsorption of heavy metals $\left(\mathrm{Pb}^{2+}, \mathrm{Co}^{2+}, \mathrm{Cu}^{2+}\right.$, $\mathrm{Zn}^{2+}, \mathrm{Mn}^{2+}, \mathrm{Fe}^{3+}, \mathrm{Cd}^{2+}, \mathrm{Ba}^{2+}, \mathrm{As}^{2+}, \mathrm{Cr}^{3+}, \mathrm{Ni}^{2+}, \mathrm{Hg}^{2+}, \mathrm{Ag}^{+}$, etc.) from aqueous solutions. Generally, the synthetic zeolites have much better removal performance than natural ones. Heavy metals-loaded zeolite could be regenerated [6, 7].

\section{Radioactive species removal}

Various processes used in the nuclear fuel cycle and in the application of radionuclides in industry, medicine, and research generate low or intermediate level liquid wastes, containing radioactive isotopes (e.g. ${ }^{137} \mathrm{Cs},{ }^{90} \mathrm{Sr},{ }^{60} \mathrm{Co},{ }^{45} \mathrm{Ca}$, $\left.{ }^{51} \mathrm{Cr},{ }^{111 \mathrm{~m}} \mathrm{Cd},{ }^{110 \mathrm{~m}} \mathrm{Ag}\right)$. Adsorption of some radioactive elements $\left(\mathrm{U}^{6+}, \mathrm{Th}^{4-}, \mathrm{I}^{+}, \mathrm{Mo}^{2+}\right.$, $\mathrm{La}^{3+}, \mathrm{Nd}^{3+}, \mathrm{Sm}^{3+}, \mathrm{Ag}^{+}, \mathrm{Cs}^{+}, \mathrm{Co}^{2+}, \mathrm{Sr}^{2+}, \mathrm{Cd}^{2+}$ ) on some natural (clinoptilolite, mesolite, analsite, etc.) and synthetic ( $\mathrm{NaA}, \mathrm{NaX}, \mathrm{NaY}, \mathrm{ZSM} 5$, etc.) zeolites are presented in [6]. Some of the main advantages of using zeolites for nuclear wastewater [7] are their resistance to degradation in the presence of ionizing radiation, their low solubility and that they can be used for long term storage of long-lived radioisotopes in stainless steel containers. The "saturated" zeolites can be also transformed into concrete, glass, or ceramic bodies, and stored indefinitely.

\section{Sea water desalination}

The reverse osmosis membrane materials for desalination have been recently reviewed as appropriate method for water desalination. According to this mechanism, MFI zeolite, which has an effective nanopore diameter of $0.51 \mathrm{~nm}$, appears suitable for separating the smaller water molecules $(0.26 \mathrm{~nm})$ from larger ions like $\mathrm{Na}^{+}$and $\mathrm{Cl}^{-}$having hydrated sizes of 0.72 and $0.66 \mathrm{~nm}$, respectively [6]. Hydroxysodalite and $\mathrm{NaA}$ zeolites (pore diameters $0.4 \mathrm{~nm}$ and $0.8 \mathrm{~nm}$, respectively) are tested using an experimental pervaporation setup. The polymerzeolite $\mathrm{NaA}$ nanocomposite membranes and those with added $\mathrm{NaX}$ nano-zeolite, being developed recently, appear to be particularly promising for ion removal from aqueous solutions.

\section{Petroleum industry and fuels}

Catalytic cracking

Catalytic cracking is the breaking of large molecules into smaller ones at elevated temperatures via the use of a catalyst (see Fig. 4). As discussed in the previous subsection, molecules will crack when subjected to severe thermal conditions without a catalyst. However, the presence of a catalyst allows for a more controlled reaction. Fluid Catalytic Cracking (FCC) is the most widely used process for the large-scale production of gasoline with high octane number [5]. 


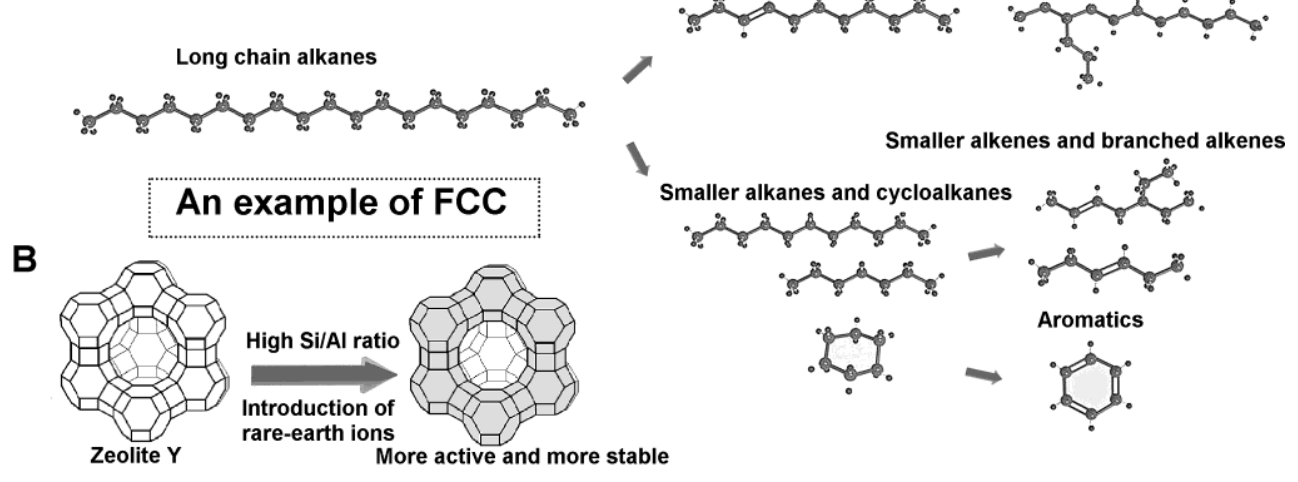

Fig. 4. Fluid catalytic cracking (FCC). A) An example of FCC.

B) Schematic of development strategies for zeolite Y for FCC catalysis.

The remarkable properties of zeolites allow the development of cleaner and more efficient processes for the production of fuels and chemicals. Because zeolites are highly porous and possess adjustable acidity, they are commonly used as absorbents, as molecular sieves for separating mixtures by selective absorption, as well as catalysts in petroleum processing.

Synthetic zeolite Y, as well as other mesoporous materials (e.g. MCM-41), are long ago used as catalysts in the petrochemical industry, for instance in fluid catalytic cracking and hydrocracking. Various different solid acidic catalysts have been studied and tested for catalytic cracking, but zeolites are the best performing ones. The Y zeolite is the main zeolitic component of the FCC process, which can be incorporated in industrial catalysts in various forms: Recently, ZSM-5 zeolite is used as a co-component to increase the yield of light olefins which are produced as secondary products. The typical reaction temperature for catalytic cracking ranges from 450 to $560{ }^{\circ} \mathrm{C}$. Examples of the various applications of zeolites and zeotypes in the catalytic conversion of oil and gas are given in the review paper of Vogt et.al. [8]. Some refinery applications are presented briefly, such as fluid catalytic cracking and hydrocracking, and also a wide variety of important petrochemical processes. Discussed are also effects of zeolite-binder interactions in commercial catalysts, where the zeolite is only part of the system.

With the right catalyst in hand, engineers may be able to steer the cracking process along a reaction path that increases cooling and generates better fuel products or ones less prone to coking. Catalysis specialists from University of Virginia have studied zeolite $\mathrm{Y}$ and its effect on the pyrolysis of JP-10 juel. Because of its compositional simplicity, JP-10 (exo-tetrahydrodicyclopentadiene) is often used in combustion research. Zeolite $\mathrm{Y}$ is a porous aluminosilicate catalyst used commercially for petroleum cracking. In the absence of the catalyst, thermal 
cracking converted JP-10 to numerous products, the predominant ones being cyclopentadiene and cyclopentene. In the presence of the catalyst, however, the fuel reacted to form naphthalene and substituted indenes. The catalyst also slightly decreased JP-10's endothermic cooling capacity and lowered the cracking temperature by $210^{\circ} \mathrm{C}$. In effect, the catalyst protects the fuel by preventing it from reaching the temperature at which hard-to-control thermal reactions take off [9].

Scientists at Tianjin University also studied the effect of zeolites on JP-10 cracking using an acidic aluminosilicate catalyst HZSM-5. They succeeded to grow nanosheets of HZSM-5 with Si/Al values of 25 (ZNS-25) and thicknesses of about $2.0 \mathrm{~nm}$. The catalytic cracking of JP-10 over ZNS-25 gave a better conversion than that obtained over a conventional bulk HZSM-5 catalyst, and the deactivation rate was relatively low. The nanosheets were more active at converting JP-10 than the respective bulk zeolites with the higher aluminium content. The explanation is that nanostructuring shortens the length of the zeolite channels and exposes more surface area for cracking. Shortening the zeolite channels enhances diffusion of reactants and products, especially the size of JP-10. And increasing the aluminium content increases the number of catalytically active acidic sites, which in the case of the nanosheets are located on the surface where they are exposed and accessible to reactants.

Gas separation, molecular sieves and adsorption

The most important property of zeolites is their internal porosity which derives from their dehydrated crystalline structure. With very active zeolites, the external surface area constitutes less than one percent of the total area available for adsorption. These materials have a great deal of internal volume available for adsorption which is only accessible by a network of channels or apertures (see Fig.1). Molecules small enough to enter the channels can access the internal volume where the crystal adsorption sites are located. Zeolites have the potential of providing precise and specific separation of gases, including the removal of $\mathrm{H}_{2} \mathrm{O}$, $\mathrm{CO}_{2}$ and $\mathrm{SO}_{2}$ from low-grade natural gas streams. Other separations include noble gases, $\mathrm{N}_{2}, \mathrm{O}_{2}$, freon and formaldehyde.

The first comprehensive published review of the design and performance of advanced oxygen systems was written in 1996 by members of the USAF Armstrong Laboratory and of the RAF School of Aviation Medicine. The evolution of on-board oxygen generating systems and the first generation of oxygen concentrators working by using molecular sieve adsorption technology are described. Such systems have been in use in the US Navy, the US Air Force and the Royal Air Force for over 20 years. They are mounted on high-performance combat aircraft and will continue to be used in the future. In 1998, the results of an American experiment were published in which 5A zeolite was used to remove $\mathrm{CO}_{2}$ at the International Space Station. The device, known as the "four-bed molecular sieve" or 4BMS, was intended to eliminate through adsorption the excess $\mathrm{CO}_{2}$ 
exhaled by the crew and on-board animals. The packed bed was filled with solid sorbent media (5A zeolite) to scrub $\mathrm{CO}_{2}$ from the air blown through it. The $\mathrm{CO}_{2}$-saturated bed was regenerated several times a day in a programmed cycle. During the regeneration cycle, the process air stream was diverted to a second (and previously regenerating). The concentrated $\mathrm{CO}_{2}$ was removed from the bed using heat and vacuum [10].

An important aspect of air revitalization for life support in spacecraft is the removal of $\mathrm{CO}_{2}$ from cabin air. Several types of $\mathrm{CO}_{2}$ removal systems are in use in spacecraft life support. These systems rely on various removal techniques that employ different architectures and media for scrubbing $\mathrm{CO}_{2}$, such as permeable membranes, liquid amine, adsorbents, and absorbents. Sorbent systems have been used since the first manned missions. The current state of key technology is the existing International Space Station (ISS) Carbon Dioxide Removal Assembly (CDRA), a system that selectively removes carbon dioxide from the cabin atmosphere. The CDRA system was launched aboard UF-2 in 2001 and resides in the U.S. Destiny Laboratory module. During the past four years, the CDRA system has operated with varying degrees of success. There have been several approaches to troubleshooting the CDRA system aimed at developing work-around solutions that would minimize the impact on astronaut time required to implement interim solutions. The CDRA is a critical piece of life support equipment in the air revitalization system of the ISS, and is demonstrated technology that may ultimately prove well-suited for use in lunar or Mars base, and Mars transit life support applications [11].

Another modern zeolite system has been described recently, in which the removal of carbon dioxide from space cabin air is under strict control. The system is integrated into a closed air regeneration cycle aboard spacecraft. The continuous operation of a double-adsorbent regeneration system with $\mathrm{CO}_{2}$-dependable productivity is maintained through programmable setting of adsorption (desorption) semicycle time. The automatically changing system productivity ensures continuous intake of concentrated $\mathrm{CO}_{2}$. Control of the adsorptiondesorption process is based on calculation of the differential adsorption (desorption) heat from gradient of adsorbent and test inert substance temperatures. The adaptive algorithm of digital control is implemented through the standard spacecraft interface with the board computer system and programmable microprocessor-based controllers [12].

Coating technology

A molecular absorber is also based on absorption property of the highly porous materials which have large specific surface area. Currently, NASA Goddard Space Flight Center has developed a sprayable coatings technology with broad application by using of zeolites, named a Molecular Adsorber Coating (MAC). The coating is comprised of highly porous zeolitic materials that help capture outgassed 
molecular contaminants on spaceflight applications. The adsorptive capabilities of the zeolite coating can alleviate molecular contamination concerns on or near sensitive surfaces and instruments within a spacecraft. The preliminary tests of NASA's MAC technology are discussed for use on future missions to Mars. The study involves evaluating the coating's molecular adsorption properties in simulated test conditions, which include the vacuum environment of space and the Martian atmosphere [13].

\section{Electrically based applications}

Electrically conducting zeolite-like frameworks are not typical electronic materials, but may offer new avenues in energy applications. Because of their superior catalytic, adsorption, and separation capabilities, zeolites can be used as cell component materials (such as electrodes and membranes). For instance, $\mathrm{CeO}_{2}$-decorated ZSM-5 zeolitic nanocatalysts could be used to make $\mathrm{CeO}_{2} / \mathrm{ZSM}$-5modified glassy-carbon electrodes for electrochemical oxidation of methanol.

Silver-zeolite composites are interesting materials with unique optical properties. Zeolites assist Ag in naturally emitting light, which could lead to new lighting technologies - supplementing or replacing fluorescent lights or LEDs. At present, the controlled synthesis of Ag-zeolite composites with responsive optical properties remains a challenge. Recently was reported the synthesis and characterization of novel LTA( $\mathrm{Li})-\mathrm{Ag}$ zeolites which display better luminescence performance, compared to LTA(Na)-Ag samples. Yellow (19\% water content), green ( $17-2 \%$ water content) and blue (less than $1 \%$ water content) emitters were observed in LTA(Li)-Ag zeolite composites with the same composition (low silver loadings) but different hydration levels. This shows the great potential that this new type of luminescent Ag-zeolite might have as blue emitting materials and as luminescence-based humidity sensors at macro and micro scale [14].

\section{Soil improvement}

The main problem in space is the limitation of life support resources. The $\mathrm{CO}_{2}$ removal from breading air in space and recycling of wastewater are two important areas of application for zeolites. Particularly promising application is the use of zeolites loaded with several substances as planting substrates and artificial soil in extra-terrestrial station to grow plants, which convert $\mathrm{CO}_{2}$ back to $\mathrm{O}$, remove excess environmental humidity and turn wastewater into drinking water.

Bulgaria is the third country in the world, after the USA and Russia, with a space greenhouse. In 1995 during the Zeolite Meeting' 95 in Sofia was presented the report "Zeolite Gardens in Space", devoted to the use of natural zeolites in space applications and occurrence in extra-terrestrial environments. These studies were initiated in the period 1950-1980 by the US Air Force and Russian scientists. In 1984, a Russian-Bulgarian group created the first space greenhouse named 
SVET. The first experiment was realized in 1990 after the equipment was installed to the MIR Orbital Station and the first fresh vegetables (radishes and Chinese cabbage) were produced in space. Result of next experiments was the growth of wheat and beans, rich in proteins. The Balkanite substrate, made from the natural zeolite clinoptilolite, extracted in the Kardzhali region, with added mineral salts, was used as the nutrient medium for growing the plants. Zeolites mixed with Mars soil could solve the problems of Mars soil bioremediation and even with formation of the atmosphere [15].

\section{Zeolite synthesis from natural and industrial products}

Natural zeolites and synthetic zeolites from natural materials

Among the most common natural zeolites are clinoptilolite, analcime, chabazite, fauhazite, ferrierite, kaolin and mordenite. Their cations are mainly alkaline $(\mathrm{Na}$ and $\mathrm{K})$ and alkaline earth $(\mathrm{Ca}$ and $\mathrm{Mg}$ ) metals. Due to their high content of $\mathrm{Si}$ and $\mathrm{Al}$, clays are often used and different zeolites (A, X, Y, P, etc.) have been synthesized [6].

Rice husk zeolites

Alkali activation of Bulgarian rice husk or rice husk ash, as sources of $\mathrm{SiO}_{2}$, and almost pure $\mathrm{Al}$ from aluminum cans resulted in zeolites Sodalite, A, X, P and Y. Pure highly crystalline and completely white zeolite NaA was successfully synthesized from untreated rice husk by means of new economical and technologically feasible procedures, avoiding the rice husk burning [16].

Synthetic zeolites from coal fly ash

Coal fly ash is the most abundant coal combustion by-product, partly used in concrete and cement manufacturing. Most of this waste is disposed in open landfills, creating serious problems with air and water pollution. The fly ash contains a significant amount of crystalline and amorphous aluminosilicates which makes him a suitable material for the synthesis of zeolites. More than 15 types of zeolites (e.g. NaA, NaX, NaY, NaP1, Sodalite, K-chabazite, Linde F, etc.) could be synthesized, and the type and yield of the zeolite obtained are strongly influenced by the chemical and mineralogical composition of the fly ash used.

Fly ashes from Bulgarian TPPs ("Maritza East 2 and 3", "Varna", "Bobovdol", "AES Galabovo", "Republika" and "Rousse East"), burning local and foreign coals, have been hydrothermally activated [7, 17-19]. At higher temperatures and different alkali concentrations the ashes were transformed into different zeolitic materials, containing zeolite Linde F, blend of zeolites A and P, or Hydroxy Sodalite [17]. The obtained synthetic zeolites of type Hydroxy Sodalite were applied as ion-exchangers in systems of nuclear safety for trapping radioactive ${ }^{137} \mathrm{Cs}$ and ${ }^{90} \mathrm{Sr}$ [7]. The highly-porous zeolite Na-X from fly ash of TPP "Maritza East" has been studied as high capacity inexpensive adsorbent of $\mathrm{CO}_{2}$ 
with application in gas separation systems [18]. Cobalt-modified zeolites showed high activity in degradation of different VOCs (acetone, n-hexane, toluene and 1,2 dichlorobenzene). It is promising candidate for development of a dual catalytic/adsorption system for VOCs and $\mathrm{CO}_{2}$ elimination [19].

\section{Slag zeolites}

The waste slag from the Bulgarian TPP "Sviloza" was alkali treated at room temperature for more than a year. The zeolited product contains zeolites $\mathrm{X}$ and Linde F. It was tested as absorbent of a textile dye from aqueous suspensions. Due to its better developed active specific surface, the dye was almost completely absorbed for much shorter times than the untreated slag [20].

\section{Conclusion}

Undoubtedly, the zeolites are a necessary and obligatory element of present and future terrestrial and space engineering. Due to their unique properties, zeolites have a great potential as effective sorbent materials for a large number of water treatment applications, such as water softening (for boilers and drinking), ammonia removal (from municipal sewage, animal farms, additives to feed, fertilizer factory wastewaters, fish breeding ponds, swimming pools), removal of heavy metals (from natural waters, acid mine drainages, industrial wastewater), phosphates removal, removal of dissolved organic compounds and dyes, oil spillages treatment, soil conditioning agents, separation of solid impurities, radioactive wastewater purification, seawater desalination, and many others.

Synthetic zeolites obtained by reprocessing of industrial and municipal wastes have huge potential as a cost-effective, environmental-friendly solution that can improve the efficiency of waste water treatment. Their low price and the additional ecological benefit (reduced mining and solid wastes disposal) increase their popularity and inspire growing interest among researchers and manufacturers worldwide.

Many more challenges remain for the future, which require the development of brand new zeolitic materials that are suitable for a huge variety of practical needs and specifications of aerospace engineering. For many decades, NASA and its international partners have been at the forefront of Mars exploration through a series of missions. Advances in space exploration and space travels need new type zeolites. Aerospace engineering is one of the most important branches of engineering and will help humankind to dominate the skies and all the space above. Aerospace engineering with the help of novel technologies will help us not just to conquer the sky, but to reach the stars, and the zeolites will be an invaluable and indispensable tool in this mission. 


\section{References}

1. Coronas, J. Present and future synthesis challenges for zeolites, Chemical Engineering Journal, 2010, 156, 236-42. doi:10.1016/j.cej.2009.11.006.

2. Van Bekkum, H., E. M. Flanigen, P. A. Jacobs, and J. C. Jansen. Introduction to zeolite science and practice. Amsterdam, Elsevier, 2001, p. 1061. ISBN: 0-444-82421-9.

3. Mardirossian, G. Fundamentals of remote aerospace technology, Chapter 3 and 4 (Book in Bulgarian). NBU, Sofia, 2015. ISBN: 978-954-535-882-1.

4. Haggerty, J. J. Spinoff'93, Chapter: Commercial use of space. Washington, NASA, 1993, p. 144. ISBN: 0-16-042100-04.

URL: https://spinoff.nasa.gov/back_issues_archives/1993.pdf

5. Sadeghbeigi, R. Fluid Catalytic Cracking Handbook, Butterworth-Heinemann, 2020, p. 386. ISBN: 9780128126639.

6. Shoumkova, A. Zeolites for water and wastewater treatment: An overview. Special Issue of the Research Bulletin of the Australian Institute of High Energetic Materials on the Global Fresh Water Shortage, 2011, ISBN: 978-0-9806811-1-6.

7. Zgureva, D., and S. Boycheva, Synthetic zeolitic ion-exchangers from coal ash for decontamination of nuclear wastewaters, BgNS Transactions-, 2015, 20, 2, 132-36. http://bgns-transactions.org/Journals/20-2/vol.20-2_11.pdf.

8. Vogt, E. T. C., G. T. Whiting, A. D. Chowdhury, and B. M. Weckhuysen. Zeolites and zeotypes for oil and gas conversion. In Advances in Catalysis, Chapter 2, 2015, 58, 143-314. ISBN 978-0-12-802126-2, ISSN 0360-0564.

9. Huang, B., U. Shrestha, R.t J. Davis, and H. K. Chelliah, Endothermic pyrolysis of JP10 with and without zeolite catalyst for hypersonic applications. AIAA Journal, 2018, 56, 4, 1616-26. DOI: 10.2514/1.J056432.

10. Mulloth, L. M., and J. E. Finn. Carbon dioxide adsorption on a 5A zeolite designed for CO2 removal in spacecraft cabins, NASA, California. 94035-1000, 1998. https://ntrs.nasa.gov/search.jsp?R=19980237902.

11. Jiao, Z., L. Jiang, J. Sun, et al. Outgassing environment of spacecraft: an overview, IOP Conf. Series: Materials Science and Engineering, 2019, 611, 012071, doi:10.1088/1757-899X/611/1/012071.

12. Chekov, Iu. F. Life support of the Mars exploration crew. Control of a zeolite system for carbon dioxide removal from space cabin air within a closed air regeneration cycle. (Article in Russian). Aviakosmicheskaia i ekologicheskaia meditsina (Aerospace and environmental medicine), 2009, 43, 2, 37-45.

13. Abraham, N. S., and D. E. Jallice. Preliminary testing of NASA's molecular adsorber coating technology for future missions to Mars. In: Proceedings of the SPIE. Soares, C. E., E. M. Wooldridge, and B. A. Matheson (Eds.). San Diego, SPIE. 2018, 10748, 41-46. doi:10.1117/12.2320400.

14. Coutino-Gonzalez, E., W. Baekelant, D. Grandjean, and J. Hofkens. Thermally activated silver-zeolite composites with responsive photoluminescence properties. Journal of Materials Chemistry C, 2015, 3, 11857-67. doi: 10.1039/C5TC02723C.

15. Ivanova, T., I. Stoyanov, G. Stoilov, P. Kostov, and S. Sapunova. Zeolite gardens in space. In: Natural zeolites. Sofia'95. Proceedings of the Sofia zeolite meeting'95. Kirov, L. Filizova, and O. Petrov (Eds.), Sofia, 1997, 3-10. PENSOFT, ISBN 9546-42-0158, 978-9-54-6420152. 
16. Shoumkova, A. and V. Stoyanova, SEM-EDX and XRD characterization of zeolite $\mathrm{NaA}$, synthesized from rice husk and aluminium scrap by different procedures for preparation of the initial hydrogel. Journal of Porous Materials, 2013, 20, 249-55. doi:10.1007/s10934-012-9594-x.

17. Shoumkova, A. and V. Stoyanova, Zeolites formation by hydrothermal alkali activation of coal fly ash from thermal power station "Maritsa 3", Bulgaria, Fuel 2013, 103, 533-41. doi:10.1016/j.fuel.2012.07.076.

18. Kalvachev, Yu., D. Zgureva, S. Boycheva, B. Barbov, and N. Petrova. Synthesis of carbon dioxide adsorbents by zeolitization of fly ash. Journal of Thermal Analysis and Calorimetry, 2015, 124, 1, 101-06. doi:10.1007/s10973-015-5148-1.

19. Popova, M., S. Boycheva, H. Lazarova et al. VOC oxidation and CO2 adsorption on dual adsorption/catalytic system based on fly ash zeolites. Catalysis Today, 2019, doi:10.1016/j.cattod.2019.06.070. (in press)

20. Pascova, R., V. B. Stoyanova, and A. S. Shoumkova, Room temperature zeolitization of boiler slag from a Bulgarian thermal power-plant. Journal of the Serbian Chemical Society, 2017, 82, 2, 227-40, doi:10.2298/JSC160807091P.

\section{ПРИЛОЖЕНИЕ НА ЗЕОЛИТИТЕ В НАЗЕМНАТА И КОСМИЧЕСКА ИНДУСТРИЯ - ОБЗОР}

\section{А. Митева, В. Стоянова}

\section{Резюме}

Този кратьк преглед е опит за систематизиране на някои от наличните исторически и по-нови данни данни за влиянието на зеолитната наука и техника върху прогреса на различни области от развитието на Земята и Космоса. Представени са основните структурни и химични свойства на природните и синтетичните зеолити. Включени са също така ценни приложения на зеолитите като катализатори, газови адсорбатори и йонообменници. Представени са най-често използваните методи за синтез на зеолити от различни материали, както и някои български разработки за рециклиране на отпадъци до зеолити. Важната роля на зеолитите като незаменим материал за подобряване качеството на почви, горива, води, въздух и т.н., необходими за нуждите на орбиталните космически станции и космическите кораби, е потвърдена с типични примери. 